\title{
Floristic Richness and the Conservation Value of Tropical Montane Cloud Forests of Dothalugala Man and Biosphere Reserve, Sri Lanka
}

\author{
E. M. S. Ekanayake1, 2, 3*, D. S. A. Wijesundara ${ }^{2}$ and G. A. D. Perera ${ }^{1,3}$ \\ ${ }^{1}$ Postgraduate Institute of Science, University of Peradeniya, Peradeniya, Sri Lanka. \\ ${ }^{2}$ Royal Botanic Gardens, Peradeniya, Sri Lanka. \\ ${ }^{3}$ Department of Botany, University of Peradeniya, Peradeniya, Sri Lanka. \\ Accepted December 28, 2013.
}

\begin{abstract}
Plant species in Tropical Montane Cloud Forests (TMCFs) of Dothalugala Man and Biosphere (MAB) Reserve were recorded in twenty six $10 \times 15 \mathrm{~m}^{2}$ experimental plots, aiming to reveal the total species richness and the richness of endemic and threatened flowering plant species in the forest canopy and the understory and, to find out the impacts of cardamom cultivation on the plant diversity of the study area. One hundred and forty eight plant species (77 tree, 46 shrub, 24 climber and one herbaceous species) belonging to 106 plant genera and 55 plant families have been found from the area examined. A high percentage endemicity of plant species $(50 \%)$ was revealed in this site due to the presence of 74 (38 tree, 29 shrub, 6 climber and one hebaceous) species endemic to Sri Lanka. Similarly, 68 out of all plant species $(45.9 \%)$ and 47 out of all endemic plant species $(63.5 \%)$ in these forests were either globally or nationally threatened. The endemic and 'Critically Endangered' Stemonoporus affinis (Dipterocarpaceae) was also found to be thrive in the area. Cardamom cultivation had caused a tremendous reduction in the floristic diversity (total number of species and the number of endemic and threatened species) and the conservation value of TMCFs in Dothalugala MAB reserve. Therefore, the cardamom cultivation and other related disturbances within and adjacent to Dothalugala MAB Reserve should be arrested for the conservation of plant diversity in this fragile ecosystem and, this will eventually contribute towards the conservation of biodiversity not only in Sri Lanka but also in the globe as a whole.
\end{abstract}

Keywords: cardamom cultivation, disturbances, endemic plants, species richness, Stemonoporus affinis, threatened plant species.

\section{INTRODUCTION}

Sri Lanka abounds a rich plant diversity with 7000 indigenous flora (Abeywickrama, 1986), including 3156 flowering plants of which 894 are endemic to Sri Lanka (Wijesundara et al., 2012). This high endemism of plant species and preceding threats have led Sri Lanka together with the Western Ghats of peninsular India to be considered as a biodiversity hotspot (Myers et al., 2000). Thus, the endemic plants of Sri Lanka are considered as an essential element which expresses the conservation value of the flora of the country. However, the conservation of Sri Lankan flora has received much less attention than its fauna (Pethiyagoda, 2012).

By referring to the Sri Lankan flora, Trimen (1885), an eminent scientist who pioneered botanical explorations in Sri Lanka, has stated that the individuality and interest of any flora lies mainly on its endemic species. Endemic plants of Sri Lanka appear to be distributed unequally across plant families as well as over space. Some plant families such as Balsaminaceae and Lauraceae contain many endemic species. Tropical Montane Cloud Forests (TMCFs) which are characterized by the presence of persistent or frequent wind-driven clouds (Hamilton et al., 1995) are always reputed for their high endemicity (Gentry, 1993; Ledo et al., 2009). For instance, five sixths of the Sri Lanka's endemic plants are reported to be included among the hill flora (Trimen, 1885).

Although TMCFs extend over less than $1 \%$ of the total land area of Sri Lanka (IUCN, 2007), these constitute many plants that are endemic to the country. As reported by Ranasinghe et al. (2006), more than $50 \%$ of the residing species in TMCFs are endemic to the country. Tropical Montane Cloud Forests in the world are not different from those in Sri Lanka either. These cover about 1.6\% of the total area of tropical mountain forests in the world (Kapos et al., 2000) and possess distinct biological communities and high levels of species

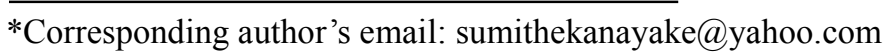


endemism and biodiversity (e.g. Gentry, 1993; Ledo et al., 2009).

In many parts of the world, the flora of TMCFs has received poor attention from scientists (e.g. Kumaran et al., 2010) though the factors affecting the formation of cloud forests and the TMCF climate had decorously been explained (e.g. Bruijnzeel and Veneklaas, 1998; Grubb, 1971; Grubb and Whitmore, 1965, 1966). The fate of TMCFs in relation to the changing climate has recently been receiving the attention of scientists (Foster, 2001; Loope and Giambelluca, 1998; Still et al., 1999). In Sri Lanka, many of the research work conducted in mountain regions of the country were related to the identification and classification of forest types, to describe the forest structure or to explain the forest climate (e.g. Balasubramaniam, 1988; Broun, 1900; de Rosayro, 1958; Gaussen et al., 1968; Greller and Balasubramaniam, 1980; Koelmeyer, 1957; Perera, 1975; Vincent, 1883; Werner, 1982). However, the high conservation value of Sri Lankan TMCFs due to the presence of endemic plant species has been acknowledged by several scientists (e.g. Green and Jayasuriya, 1996; Jayasuriya et al., 1988; Rathnayake, 1994; Wijesundara, 1991). Much of this work appears to be based on field surveys. However, some quantitative studies had also been conducted in different places, viz., Corbert's Gap and Rangala of the Knuckles massif (Jayasuriya et al., 1988), Agra Bopath and some parts of the Kelani valley forest of the Peak Wilderness area (Nisbet, 1961), Hakgala Strict Nature Reserve (Rathnayake and Jayasekara, 1998; Wijesundara, 1991) and Thangappuwa and Kalupahana of the Knuckles massif (Rathnayake, 1994).

All over the world, the number of species threatened with extinction far exceeds the conservation resources available and this situation appears to be becoming worse (Myers et al., 2000). Frequent disturbances and subsequent diminishing of the forest cover, especially in ecologically sensitive areas may have led many plant species to be extinct from the earth. Conversion of forests to agricultural land, fuel wood extraction (Sarmiento, 1995), illegal logging (Aubad et al., 2008) and human population densities and trends (Young and León, 1995) have been cited as major threats to TMCFs, leading to their fragmentation or disappearance. Thus, in Sri Lanka, 3,000 ha of montane forests are left in the island at present (Wijesundara, 2012). In the Knuckles region of Sri Lanka, cardamom cultivation has clearly been identified as a major cause towards the destruction of forested land, leading to the loss of biodiversity and increased soil erosion (Gunawardana, 2003) and, reduction in the total species richness and the richness of endemic plant species (Adikaram and Perera, 2005). In addition, many plant species endemic to Sri Lanka have been assessed as threatened by the IUCN's Red Listing process (The National Red List of Flora and Fauna of Sri Lanka, 2012). In light of this, as many as 61 endemic flowering plant species (including 23 trees) in Sri Lanka had not been recorded in the preceding 50 years (Pethiyagoda, 2012) presumably due to their extinction from the wild.

Diverse climatic conditions, which resulted due to high geographical heterogeneity as well as due to its positioning in the Sri Lankan terrain, have led the Knuckles massif to possess a wide range of rainfall and temperature regimes (Cooray, 1998; Legg, 1995). These may have potentially paved the path for the area to harbor a rich biodiversity with a high percentage of endemicity. Being located at a unique environment, TMCFs at Dothalugala may possess many more endemic plants too. A detailed quantitative survey in the forests of Dothalugala MAB Reserve area was therefore conducted. However, the current paper evaluates only the plant species taller than $1 \mathrm{~m}$ recorded in the experimental plots established, to reveal the floristic richness and the endemic and threatened plant species under different life form categories. This study also assesses the impacts of cardamom cultivation on the examined floristic features of TMCFs. The objective of this article is to provide a status quo report of the floristic richness and the conservation importance of the flora of the Reserve, but not to explain the spatial patterns of species abundances.

\section{MATERIALS AND METHODS \\ Study site}

The Knuckles massif of Sri Lanka is situated north of the central highlands of the country, as an isolated mountain range which is separated from the main highlands by the Dumbara valley. Dothalugala MAB Reserve extends over the southern and south eastern parts of the Knuckles Conservation Region $\left(7^{\circ} 17^{\prime}-7^{\circ} 21^{\prime} \mathrm{N}\right.$ and $80^{\circ}$ $49^{\prime}-80^{\circ} 57^{\prime}$ E) (Fig. 1). The presence of 'Dothalu trees' (Loxococcus rupicola, Family: Arecaceae) which is endemic to Sri Lanka has led to name this area as Dothalugala by the local people (Fig. 2). 


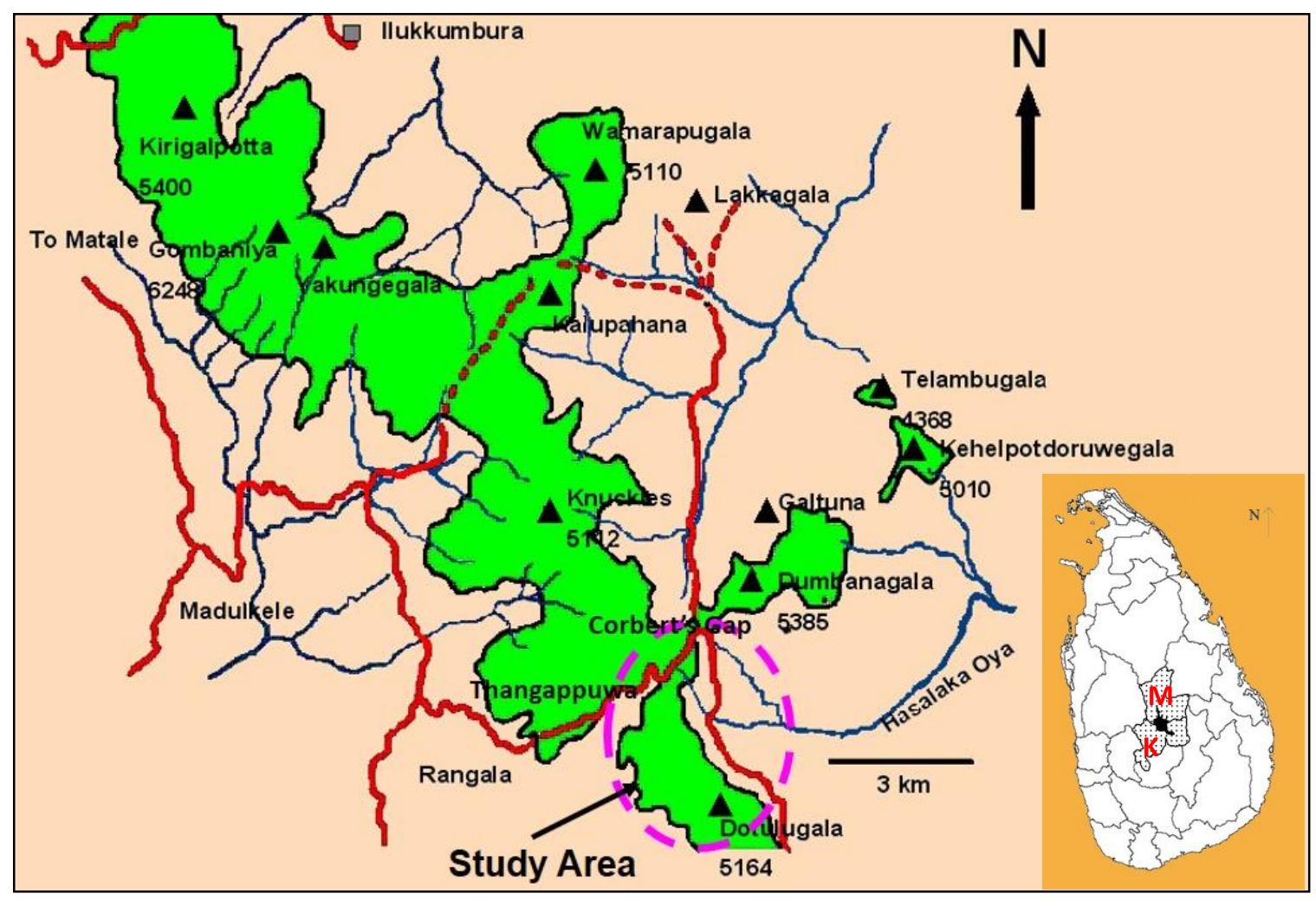

Figure 1. Location of the Knuckles mountain range in relation to the Kandy (K) and Matale (M) Districts of Sri Lanka and the location of the study area (Source: 1:50,000 map of the Survey Department of Sri Lanka).

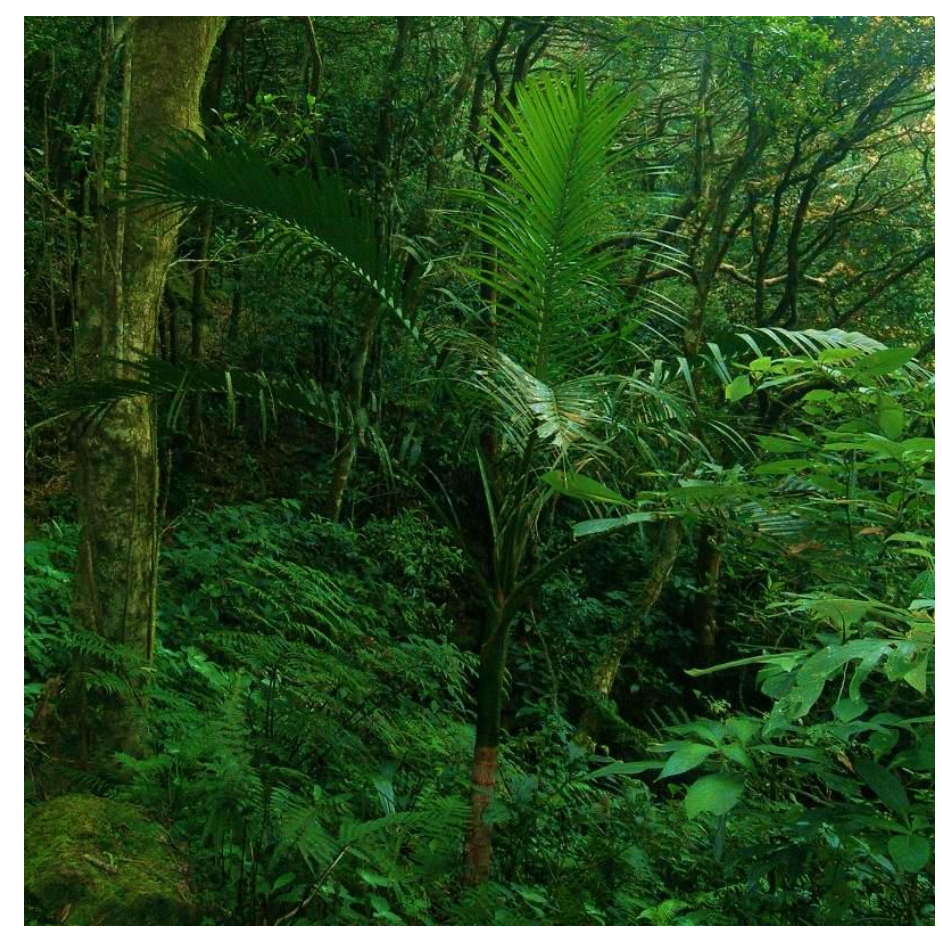

Figure 2. A juvenile Dothalu (Loxococcus rupicola) tree in the Dothalugala forest (the palm tree at the center of the photograph). 
The Dothalugala Man and Biosphere Reserve extends over 1620 ha area (Bharathie, 1989). It consists of three peaks, namely Dothalugala $\left(\begin{array}{ll}1558 & \mathrm{~m}\end{array}\right)$, Nawanagala $\left(\begin{array}{lll}1420 & \mathrm{~m}\end{array}\right)$ and Kobonillagala $(1545 \mathrm{~m})$. As stated by Cooray (1998), the average annual rainfall varies from about $2540 \mathrm{~mm}$ on the Eastern side to 3810-5080 $\mathrm{mm}$ on the main Knuckles range. Both Southwestern and North-eastern monsoonal rains directly influence the distribution of rainfall within the Knuckles massif as it is located almost perpendicular to the direction of the respective wind currents (de Rosayro, 1958; Legg, 1995; Werner, 1982). However, the lower eastern slopes are much drier, with less than $2000 \mathrm{~mm}$ of mean annual rainfall, most of which is received during the north-east monsoon (October to January) (Legg, 1995). The mean annual temperature outside the massif is more than $26{ }^{\circ} \mathrm{C}$ and this value falls down to about $21{ }^{\circ} \mathrm{C}$ at altitudes above $915 \mathrm{~m}$ and to about $18.5^{\circ} \mathrm{C}$ at the highest altitudes (Cooray, 1998). Mountain tops in the area are frequently covered with mist or fog though these at the eastern slope may drift away with the wind during the day time.

Easily accessible drier parts have been disturbed mostly for cardamom (Elettaria cardamomum) cultivation. Cardamom is a perennial spice plant which has been introduced to Sri Lanka in 1805 (Gunawardana, 2003). The government has granted permission to cultivate cardamom in forested lands on lease and people have cleared the understory of montane forests to various extents; from 3 ha to more than 20 ha to cultivate cardamom (Gunawardana, 2003). A few such cultivated lands within the Dothalugala area have been abandoned 15-20 years ago and are currently under a natural process of vegetation succession.

\section{Sampling}

Twenty six $15 \mathrm{~m}$ x $10 \mathrm{~m}$ experimental plots were established at randomly chosen points in forests of Dothalugala MAB Reserve and the individuals taller than $1 \mathrm{~m}$ were enumerated. Among these 26 experimental plots, 14 were located on wetter parts and at the ridge tops, 8 were located at the drier eastern slopes of the Dothalugala mountain range while 4 were located at abandoned cardamom cultivation sites at the dry face of the mountain range. Voucher specimens were collected from all the individuals and identified using standard keys, Flora and by comparing with those in the National Herbarium, Peradeniya. The endemic and threatened plant species among these were identified using Floras and plant checklists. Plants were categorized as trees, shrubs, climbers, herbs etc. based on the basic life form features. However, the 'climber' category in this study includes both woody and semi-woody climbing plants.

\section{RESULTS AND DISCUSSION}

Many criteria based on floristic features have often been used in determining the conservation value of wilderness areas and prioritizing habitats for conservation. Some of these include the total species richness (Gentry, 1992; Trigas et al., 2013), endemicity of plants (Brooks et al., 2006; Gentry, 1992; Trigas et al., 2013), threat status of candidate species (Redding and Mooers, 2006) and rarity of species (Margules and Usher, 1981; Scott et al., 1993; Singh and Samant, 2010 and Usher, 1986). Total species richness per se may not truly represent the conservation value of a given area. This is because, the species richness can be driven by common, widespread species. (Orme et al., 2005; Lamoreux et al., 2006). The use of species richness in prioritizing habitats may create serious conceptual errors due to its dependency on the size of the area sampled and the sizes of individuals in each locality. In this sense, Hurlbert's (1971) rarefaction method proved to be robust to compare the plant species richness among habitats as the method standardizes all samples to a common size. It is a common belief that habitats that are rich in species for one taxon may also be species-rich for other taxa as well (Pearson and Cassola, 1992) and therefore, the rare species may benefit from the conservation of species rich habitats (Soulé, 1986), though this may not be equally applicable to all the ecosystems in different parts of the world (Prendergast et al., 1993).

Rarity of species of a given site is also an important criterion to be considered but this remains difficult to quantify. Moreover, the concept of rarity has often been used in an ambiguous way in vegetation science by different authors. Some have used the term with reference to the frequency of occurrence while others have used the term to describe the abundance of participating species (Jesús, 1998).

In contrast, the degree of biotic endemism is often considered as a major criterion that is used in determining the conservation units (Gentry, 1992). Similarly, the threat status of species which has been introduced by the IUCN (World Conservation Union) provides good information on the conservation value of species (Gärdenfors et al., 2001). It gives guidelines to assign species 
into categories of threat, based on threshold values of population parameters, such as range of occurrence and population decline (Redding and Mooers, 2006). Thus, it appears that it is easy and reasonable to describe the plant diversity and the conservation value of a given habitat by the total species richness together with the endemicity and the threat status of species in the site.

\section{Floristic richness and the conservation value of TMCFs at Dothalugala MAB Reserve Species richness}

One hundred and forty eight flowering plant species belonging to 106 genera and 55 plant families were identified from the examined two forest strata (Appendix 1). Among these, there were 77 tree, 46 shrub, 24 climber and one herbaceous species. However, the species richness in the study site could be much higher than the recorded if all plant groups were considered. This is due to the fact that epiphytic and cryptogamic plants that prefer cooler and wetter environments thrive well in montane forests (Jacobs, 1988; White, 1983 and Whitmore, 1975).

\section{Endemic plant species}

The current study revealed a high endemicity of flowering plants at Dothalugala MAB Reserve (Appendix 1). Seventy four endemic plants species of Sri Lanka were found from the forests and this accounts for $50 \%$ of the total number of plant species that reside in the area. Of these, 38 were trees, 29 were shrubs, 6 were climbers while only one was a herbaceous species. Results of the present study were comparable with those received from other TMCFs of the Knuckles massiff. For instance, $50 \%$ of the residing plant species at Thangappuwa were endemic to Sri Lanka (Rathnayaka 1994). Further, the endemicity of plants at Dothalugala forests could be much higher if all the vegetation including herbaceous and epiphytic flora were included. A greater number of species in the plant families such as Balsaminaceae and Lamiaceae are herbaceous and as Cramer (2006) explained these two are among the families which contain a high number of endemic plant species of the country.

Out of the 74 endemic plant species, 42 (56.7\%) were found to occur commonly all over the Reserve. Agrostistachys coriacea (Fig. 3a), Calophyllum trapezifolium, Eurya ceylanica, Semecarpus nigro-viridis, Kendrickia walkeri (Fig. 3b) and Glochidium pachycarpum (Fig. 3c) were some of the common endemic species found in the forests. In contrast, some species occurred less frequently or were highly restricted to specific localities within the reserve. Such a pattern appears to be common in other TMCFs as well. Analysis of habitat associations of tree species with respect to the terrain characteristics had shown that $36 \%$ of compositional variability in montane sites could be explained by elevation (Jarvis, 2001). In Dothalugala, species such as Osbeckia lanata and Stemonoporus affinis thrive well in ridge tops while Litsea walkeri, Vernonia zeylanica and Fahrenheitia minor appear to be of restricted distribution and confined to drier slopes of the Reserve. However, no point endemics have been recorded from the two forest strata in the area explored.

The endemic tree, Stemonoporus affinis (Fig. 3d) which belongs to the family Dipterocarpaceae, was found to occur mainly on ridge tops of Dothalugala MAB Reserve. Members of the family Dipterocarpaceae are usually reported to be common in lowland humid forests which are normally restricted up to a height of $1200 \mathrm{~m}$ on main mountain ranges and, $900 \mathrm{~m}$ or lower altitudes on isolated mountains of the Malay Peninsula and other parts of South-east Asia, India, Sri Lanka and in Africa (Greller et al., 1987; Symington (1943). However, Greller et al. (1987) stated that some species of the genus Stemonoporus commonly occur above $1500 \mathrm{~m}$ and up to $1800 \mathrm{~m}$ in the TMCFs of Sri Lanka.

\section{Threatened plant species}

All the plant species identified from the study area were evaluated against the National and Global Lists of threatened plants as given in the National Red List of Flora and Fauna of Sri Lanka, 2012. Among the 148 plant species found at Dothalugala MAB Reserve, 57 (38.5\%) were found to be nationally threatened species (Table 1). These include 30 tree, 18 shrub, 8 climber and one herbaceous species. Similarly, 17 tree and shrub species $(11.5 \%$ of the total species) that grow in the study area were found to be globally threatened (Table 2). However, 6 species have been included in both National and Global Red Lists. As given in Table 1, there are 11 other Near Threatened species as well.

Two critically endangered plant species, viz. Memecylon sessile (Melastomataceae) and Stemonoporus affinis (Fig. 3d) were found from the study area. The shrub, M. sessile is locally common at Dothalugala MAB Reserve and this is not an endemic species. In contrast, as mentioned elsewhere in this article, S. affinis is endemic to Sri Lanka and is listed as a 'Critically Endangered' species in both National and Global Threatened Lists. 
According to the National Red List of Sri Lanka, 15 (7 tree, 6 shrub and 2 climber) species of TMCFs of Dothalugala fall into nationally 'Endangered' category. Of these, Syzygium caryophyllatum (Myrtaceae) is considered as an endangered species at global scale too. The species appeared to be restricted to the drier eastern slopes of the mountain range. Similarly, some nationally endangered species such as Arundinaria debilis and Elaeocarpus hedyosmus were found to be restricted to wetter parts of Dothalugala MAB reserve. In addition, species like Osbeckia lanata and Ternstroemia gymnanthera appeared to be confined to ridge tops with a dense cloud cover but some like Dioscorea trimenii and Ilex denticulata apparently avoided ridge tops. In contrast, several other endangered species such as Cinnamomum litseaefolium, Gordonia ceylanica, Hortonia floribunda, Litsea glaberrima, Memecylon cuneatum, Symplocos cordifolia (Fig. 3e) and Syzygium fergusoni (Fig. 3f) were found to be thriving well throughout the study area.
Moreover, 40 (nationally) vulnerable plant species were found in these relatively undisturbed forested areas (Table 1). These include 22 tree, 11 shrub, 6 climber and 1 herbaceous species. About half of these exhibits a distribution spanning the entire study area. Others show a more restricted distribution and are confined to ridge tops, wetter sites or to the dry slopes of the mountain range.

The current study further revealed that many of the endemic plant species found in the Reserve area were listed as threatened either at national or global levels (The National Red List of Flora and Fauna of Sri Lanka, 2012). Among the 74 endemic species that were found from the natural forests of Dothalugala MAB reserve area, 40 $(54 \%)$ species have been listed as nationally threatened species (Table 3) while 13 (17.5\%) have been listed as globally threatened species. Among these, 6 plant species are included in Red Lists at both national and global scales.

Table 1. Number of nationally 'Threatened' and 'Near Threatened' plant species of Sri Lanka that were found at Dothalugala MAB Reserve area as per the National Red List of Flora and Fauna of Sri Lanka, 2012 (Species names are given in the Appendix I).

\begin{tabular}{|c|c|c|c|c|c|}
\hline & \multicolumn{5}{|c|}{ Number of plant species } \\
\hline & Trees & Shrubs & Climbers & Herbs & Total \\
\hline Critically Endangered & 1 & 1 & 0 & 0 & 2 \\
\hline Endangered & 7 & 6 & 2 & 0 & 15 \\
\hline Vulnerable & 22 & 11 & 6 & 1 & 40 \\
\hline $\begin{array}{l}\text { Total no. of Threatened } \\
\text { species }\end{array}$ & 30 & 18 & 8 & 1 & 57 \\
\hline $\begin{array}{l}\text { No. of Near Threatened } \\
\text { species }\end{array}$ & 5 & 5 & 1 & 0 & 11 \\
\hline
\end{tabular}

Table 2. Number of globally 'Threatened' plant species in Dothalugala MAB Reserve area as per the National Red List of Flora and Fauna of Sri Lanka, 2012 (Species names are given in the Appendix I).

\begin{tabular}{lccccc}
\hline & \multicolumn{5}{c}{ Number of plant species } \\
\cline { 2 - 6 } & Trees & Shrubs & Climbers & Herbs & Total \\
\hline Critically Endangered & 1 & 0 & 0 & 0 & 1 \\
Endangered & 3 & 0 & 0 & 0 & 3 \\
Vulnerable & 10 & 3 & 0 & 0 & 13 \\
\hline $\begin{array}{l}\text { Total no. of Threatened } \\
\text { species }\end{array}$ & 14 & 3 & 0 & 0 & 17 \\
\hline
\end{tabular}



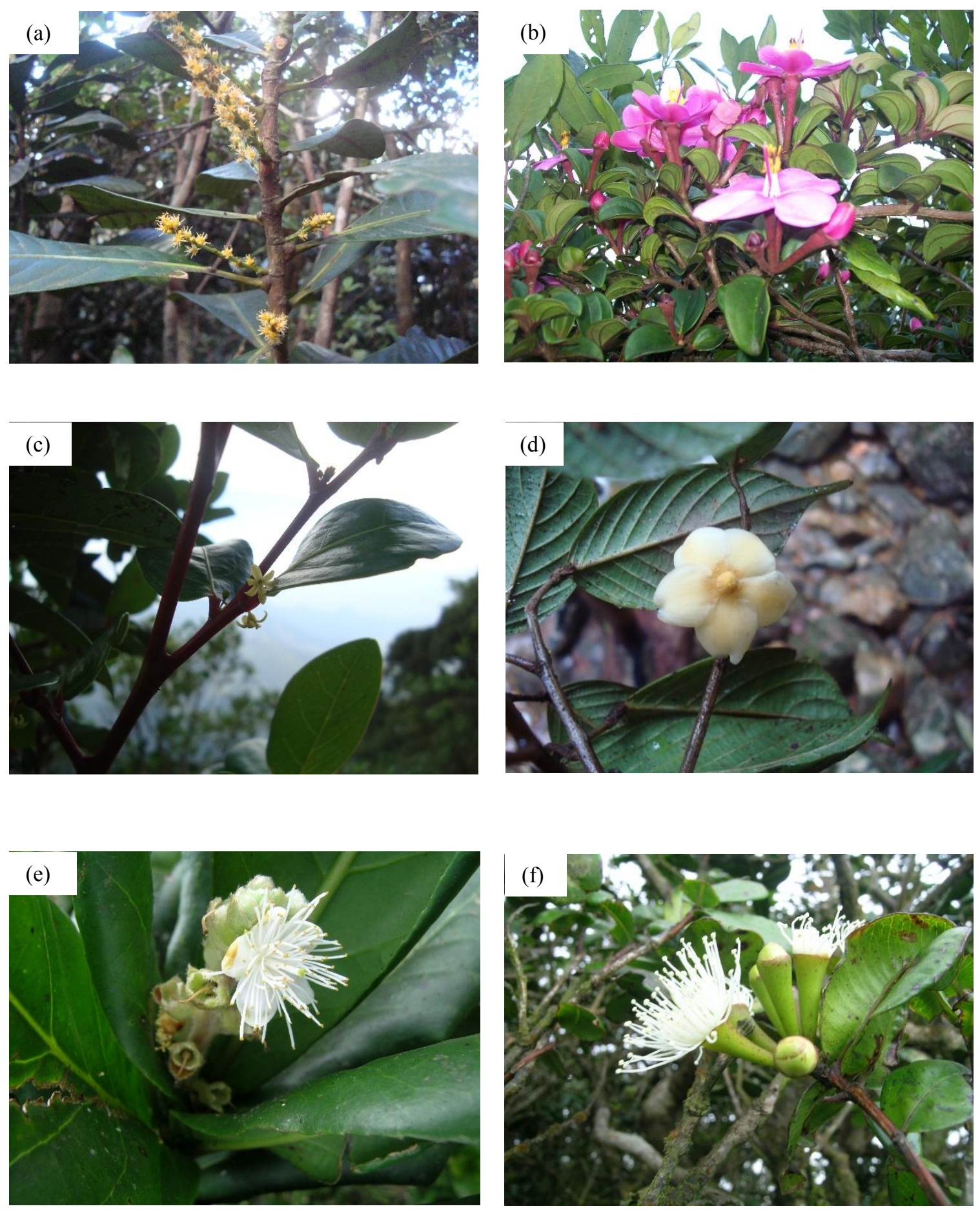

Figure 3. (a) Agrostistachys coriacea (E, VU-N), (b) Kendrickia walkeri (E), (c) Glochidium pachycarpum (E), (d) Stemonoporus affinis (E, CR-N, CR-G), (e) Symplocos cordifolia (E, VU-N, EN-G) and (f) Syzygium fergusonii (E, VU- N, EN-G) [E - Endemic; CR - Critically Endangered; EN - Endangered; VU vulnerable; $\mathbf{N}$ - Nationally threatened; $\mathbf{G}$ - Globally threatened] 
Table 3. Number of 'Threatened' and 'Near Threatened' endemic plant species of Sri Lanka that occur at Dothalugala MAB Reserve area according to the National Red List of Flora and Fauna of Sri Lanka, 2012 (Species names are given in the Appendix I).

\begin{tabular}{lccccc}
\hline & \multicolumn{5}{c}{ Number of endemic plant species } \\
\cline { 2 - 6 } & Trees & Shrubs & Climbers & Herbs & Total \\
\hline Critically Endangered & 1 & 0 & 0 & 0 & 1 \\
Endangered & 5 & 5 & 1 & 0 & 11 \\
Vulnerable & 14 & 10 & 3 & 1 & 28 \\
\hline Total Threatened species & 20 & 15 & 4 & 1 & 40 \\
\hline Near Threatened species & 1 & 4 & 0 & 0 & 5 \\
\hline
\end{tabular}

\section{Impacts of disturbances on endemic and threatened flora in the area}

The floristic features of abandoned cardamom cultivation lands were compared with those of adjacent relatively less disturbed sites in the dry parts of the mountain range as given in the Table 4. Floristic richness (number of plant families, genera, total species and species of endemic and threatened taxa) in secondary forests grown after the abandonment of cardamom cultivation was lower than that in adjacent, relatively less disturbed forests in the drier slopes of the mountain (Table 4). Nearly one third of the plant families and genera and half of the natural forest species have disappeared from the land as a consequence of cardamom cultivation. A fewer number of tree and shrub species were present in secondary forests that have emerged after the abandonment of cardamom cultivation (Table 4).

Table 4. Comparison of floristic features of TMCFs and adjacent abandoned cardamom cultivation sites at the dry-face of the mountain range

\begin{tabular}{lcc}
\hline & \multicolumn{2}{c}{$\begin{array}{c}\text { Number of taxa in the two vegetation types at the } \\
\text { North-eastern slope of the mountain range }\end{array}$} \\
\cline { 2 - 3 } Floristic feature & $\begin{array}{c}\text { Relatively less disturbed } \\
\text { natural forests }(\mathrm{n}=8)\end{array}$ & $\begin{array}{c}\text { Abandoned cardamom } \\
\text { cultivation sites (n=4) }\end{array}$ \\
\hline Plant families & 47 & 30 \\
Plant genera & 82 & 50 \\
Plant species & 104 & 61 \\
Life form & & \\
$\quad$ rree species & 56 & 32 \\
$\quad$ Shrub species & 31 & 17 \\
$\quad$ Climber species & 17 & 12 \\
Nationally Threatened species & & 0 \\
$\quad$ Critically Endangered & 1 & 3 \\
$\quad$ Endangered & 9 & 16 \\
$\quad$ Vulnerable & 29 & 7 \\
Near Threatened (nationally) species & 9 & 2 \\
Globally Threatened species & & 5 \\
$\quad$ Endangered & 3 & 30 \\
Vulnerable & 11 & 2 \\
Endemic species & 55 & 13 \\
Nationally Threatened endemic species & & 3 \\
$\quad$ Endangered & 6 & \\
Vulnerable & 22 & \\
Near Threatened (nationally) endemic species & 5 & \\
\hline
\end{tabular}


However, it was evident that many pioneer or exotic species such as Macaranga indica and Clidemia hirta thrive well in these disturbed sites. Although the number of experimental plots established in the two forest categories were different, this would not much affect the pattern explained and any ecologist who visits the two sites can easily detect this by visual observation.

Only 30 endemic plant species were found in abandoned cardamom cultivation sites and almost all of these were widely occurring species in the study area. Some other endemic plant species, most of which may need specific microhabitats, did not occur in the site even 15-20 years after the abandonment of cardamom cultivation. 'Critically Endangered' Memecylon sessile was also not found to occur in these secondary forests though the species was frequently found in relatively undisturbed natural forests.

The results of the current study are comparable with a similar study carried out at Kaelaebokka, towards Rangala of the Knuckles massif. There, approximately a $50 \%$ reduction of species was noticed in abandoned cardamom cultivated sites compared with the adjacent relatively less disturbed areas, while the endemicity of trees was as low as $22 \%$. Some nationally endangered plant species such as Elaeocarpus montanus and Gordonia zeylanica, globally vulnerable Antidesma pyrifolium, nationally vulnerable Calophyllum tomentosum and, many endemic plant species of the country including Lasianthus oliganthus and Syzygium micranthum were absent in cardamom cultivation lands (Adikaram and Perera, 2005).

The decline of the floristic richness and the conservation value of the secondary forests investigated may be an artifact of past disturbances due to cardamom cultivation. During cardamom cultivation, the understory and ground layers are cleared (Gunawardana, 2003) and as a result, many tree, climber and herbaceous flora in the ground and understory layers are removed. Tree canopy is also damaged during cardamom cultivation so as to allow more light to penetrate to the ground layer (Gunawardana, 2003; Ranawana et al., 2004). Gunawardana (2003) pointed out that these cardamom cultivation lands were also frequently found on the slopes of $30-70 \%$ steep terrain and on stream banks which were highly environmentally sensitive areas situated over an elevation of $1000 \mathrm{~m}$. THESE Cardamom cultivation lands are frequently been cleaned and as a result, the soil erosion takes place (Gunawardana, 2003). Prolonged cardamom cultivation therefore, proved to remove many native plant species from the sites and the remaining plants could be a choice of the cardamom growers. At present, there is an increasing trend to grow plant species alien to the region (e.g. Alstonia scholaris, Artocarpus heterophyllus) by cardamom growers to cover canopy gaps that have occurred due to the death of native canopy trees. This salient change of species composition in cardamom cultivation lands would potentially hasten the complete devastation of this fragile ecosystem. It is true that cardamom cultivation is a profitable industry. However, in the Knuckles region, the majority of those engaged in cardamom cultivation is represented by the elites from different parts of the country whereas only a few local rural villagers may be involved in cardamom cultivation at small-scale. In addition, a vast majority of the local villagers serve as labourers in the cardamom industry and thus, this venture would not much support the rural development in the region.

\section{Concluding remarks}

The current study revealed the high plant species richness and high conservation value of TMCFs of Dothalugala while reiterating the irreparable consequences and effects of cardamom cultivation on this globally valued ecosystem. This situation is more or less the same for other parts of the Knuckles massif too. Therefore, measures should be taken to reassess the possible options for this incomparable land. Could we afford to achieve sustainable development at the cost of the biodiversity of our country? Would cardamom cultivation in this environmentally sensitive area be a sensible option for this region? Would not the development of ecotourism industry in the Knuckles region with the participation of local people be a better alternative for the sustainable development of the country? Therefore, we firmly propose strict protection of this fragile and invaluable resource through change of existing policies and strengthening of relevant institutes.

\section{ACKNOWLEDGEMENTS}

Financial assistance provided by the National Science Foundation, Sri Lanka (Grant No.: $\mathrm{RG} / 2003 / \mathrm{FR} / 02$ ) and the kind permission granted by the Forest Department of Sri Lanka for conducting this study at Dothalugala MAB Reserve are gratefully acknowledged. Authors 
also wish to extent their sincere gratitude to $\mathrm{Mr}$. B. K. B. Waththegama and Mr. B. D. C. G. Priyantha of the Forest Department for providing facilities during field activities, Mr. Milinda Bandara and Mr. Palitha Chandrasiri for helping in the field, Ms. Ranjani Edirisinghe of the National Herbarium, Peradeniya for assisting in the identification of plant species and Mr. Rusiru Hemage for assisting in preparing the map of Sri Lanka in the Figure 1.

\section{REFERENCES}

Abeywickrama, B. A. (1986). The Threatened Plants of Sri Lanka. UNESCO and MAB National committee for Sri Lanka. Publication No 16. NARESA, Colombo, Sri Lanka.

Adikaram, N. W. A. M. M. D. and Perera, G. A. D. (2005). Impacts of Cardamom cultivation on the floristic diversity of the montane forests of the Knuckles Range. Proceedings of the University of Peradeniya Annual Research Sessions 2005, University of Peradeniya, Sri Lanka.

Aubad, J., Arago'n, P., Olalla-Ta'rraga, M. A. and Rodríguez, M. A. (2008). Illegal logging, landscape structure and the variation of tree species richness across North Andean forest remnants. Forest Ecology and Management 255: 1892-1899.

Balasubramaniam, S. (1988). The major forest formation of the Knuckles region. Proceedings of the Preliminary workshop for the preparation of a conservation plan for the Knuckles range of forest, Forest Department, Colombo, Sri Lanka.

Bharathie, K. P. S. (1989). Impacts on the Knuckles Range of Forest in Sri Lanka. Forest Department. Colombo, Sri Lanka.

Brooks, T. M., Mittermeier, R. A., da Fonseca, G. A. B., Gerlach, J., Hoffmann, M., Lamoreux, J. F., Mittermeier, C. G., Pilgrim, J. D. and Rodrigues, A. S. L. (2006). Global biodiversity conservation priorities. Science 313: 58-61.

Broun, A. F. (1900). On the forest and waste land of Ceylon. In: The flora of Ceylon, Hand book, ed. H. Triman. Royal Botanic gardens, Peradeniya, Sri Lanka, Volume 5: 355-363.

Bruijnzeel, L. A. and Veneklaas, E. J. (1998). Climatic conditions and tropical montane forest productivity: The fog has not lifted yet. Ecology 79 (1): 3-9.

Cooray, P. G. (1998). The Knuckles Massif - A Portfolio. Forest Department, Sri Lanka.

de Rosayro, R. A. (1958). The climate and vegetation of the Knuckles region of Ceylon. Ceylon Forester 3 (3/4): 201-260.

Foster, P. (2001). The potential negative impacts of global climate change on tropical montane cloud forests. Earth-Science Reviews 55 (12): 73-106.

Gärdenfors, U., Hilton-Taylor, C., Mace, G. M. and Rodríguez, J. P. (2001). The Application of IUCN Red List Criteria at Regional Levels. Conservation Biology 15(5): 1206-1212. DOI: $10.1111 / \mathrm{j} .1523-1739.2001 .00112 . x$

Gaussen, H., Legris, P., Viart, M. and Labroue, L. (1968). Explanatory Notes on the Vegetation Map of Ceylon. Govt. Press, Colombo. 14.

Gentry, A. H. (1992). Tropical forest biodiversity: distributional patterns and their conservational significance. Journal of Oikos 63: 19-28.

Gentry, A. H. (1993). Patterns of and floristic composition in neotropical montane forests. Proceedings of Neotropical Montane Ecosystem Symposium, New York.

Green, M. and Jayasooriya, M. (1996). Lost and found. Sri Lanka's rare and endemic plant revealed. Plant Talk 18-21.

Greller, A. M., Gunatilleke, I. A. U. N., Jayasuriya, A. H. M., Gunatilleke, C. V. S., Balasubramaniam, S. and Dassanayake, M. D. (1987). Stemonoporus dominated montane forests in the Adam's Peak Wilderness, Sri Lanka. Journal of Tropical Ecology 3 (1): 243-253.

Greller, A. M. and Balasubramaniam, S. (1980). A preliminary floristic-climatic classification of the forest of Sri Lanka. The Sri Lanka Forester 14: 163-170.

Grubb, P. J. (1971). Letter on interpretation of the 'Massenerhebung' effect on tropical mountains. Journal of Nature 229: 44-45.

Grubb, P. J. and Whitmore, J. (1965). A comparison of montane and lowland rain forest in Ecudor II. The climate and its effects on the distribution and physiognomy of the forest. Journal of Ecology 53: 422-463.

Grubb, P. J. and Whitmore, T. C. (1966). A comparison of montane and lowland rain forest in Ecuador. II The climate and its effects on the distribution and physiognomy of the forest. Journal of Ecology 54: 303-333.

Gunawardana, H. G. (2003). Ecological Implication of Cardamom Cultivation in the high altitudes of Knuckles Forest Reserve, Sri Lanka. The Sri Lanka Forester 26: 1-9.

Hamilton, L. S., Juvik, J. O. and Scatena, F. N. (1995). Tropical montane cloud forests. Ecological Studies (Germany), Vol. 110. Springer-Verlag, New York. 
Hurlbert, S. H. (1971). The non-concept of species diversity: a critique and alternative parameters. Ecology 52: 577-586.

IUCN (2007). The 2007 Red List of Threatened Fauna and Flora of Sri Lanka. IUCN, Sri Lanka.

Jacobs, M. (1988). The tropical rain forest: A first encounter. Springer-Verlag, Berlin, 295pp.

Jarvis, A. J. (2001). Terrain controls on the distribution of tree Species diversity and structure in tropical Lowland and tropical montane forest. A thesis submitted to the University of London for the Degree of Doctor of Philosophy, King's College, London, U.K.

Jayasuriya, A. H. M., Balasubramaniam, S., Greller, A. M. and Dasanayake, M. D. (1988). Botany of the Knuckles Mountain Range (Unpublished).

Jesús, I. (1998) Types of rarity of plant communities. Journal of Vegetation Science 9(5): 641-646.

Kapos, V., Rhind, J., Edwards, M., Ravilious, C. and Price, M. (2000). Developing a map of the world's mountain forests. In: Price, M. F. \& Butts, N. (Eds.) Forests in Sustainable Mountain Development: A State of Knowledge Report for 2000, pp. 4-9. CAB International, Wallingford, UK.

Koelmeyer, K. O. (1957). Climatic classification and the distribution of vegetation in Ceylon. The Ceylon Forester 3 (2): 144-163.

Kumaran, S. Perumal, B., Davison, G., Ainuddin, A. N., Lee, M. S. and Bruijnzeel, L. A. (2011). Tropical montane cloud forests in Malaysia, Current status of knowledge. In: Tropical Montane Cloud Forests; Science for Conservation and Management. International Hydrology Series. L. A. Bruijnzeel, F. N. Scatena, L. S. Hamilton (Eds.), Cambridge University Press, U.K.

Lamoreux, J. F., Morrison, J. C., Ricketts, T. H., Olson, D. M., Dinerstein, E., McKnight, M. W. and Shugart H. H. (2006). Global tests of biodiversity concordance and the importance of endemism. Nature 440: 212-214.

Ledo, A., Montes, F. and Condes, S. (2009). Species dynamics in a montane cloud forest: identifying factors involved in changes in tree diversity and functional characteristics. Forest Ecology and Management 2585: 575584.

Legg, C. (1995). A Geographic information system for planning and managing the Conservation of tropical forest in the Knuckles Range. The Sri Lanka Forester, Special issue: 25 - 36.

Loope, L. L. and Giambelluca, T. W. (1998).
Vulnerability of island Tropical Montane Cloud Forests to climate change, with special reference to East Maui, Hawaii. Climatic Change 39(2-3): 503-517.

Margules, C. and Usher, M. B. (1981). Criteria used in assessing wildlife conservation potential: a review. Biological Conservation 21: 79-109.

Myers, N., Mittermeler, R. A., Mittermeler, C. G., da Fonseca, A. B. and Kent, J. (2000). Biodiversity hotspots for conservation priorities. Nature 403: 853 - 858.

Nisbet, R. H. McD. (1961). A Forest Inventory of the Peak Wilderness - Agra Bopats Fores Area and Part of the Kelani Valley Forest Area. Ceylon Government Press, Colombo.

Orme C. D. L., Davies R. G., Burgess, M., Eigenbrod, F. and Pickup, N. (2005). Biodiversity hotspots of species richness, threat, and endemism are not congruent. Nature 436: 1016-1019.

Pearson, D. L. and Cassola, F. (1992). WorldWide Species Richness Patterns of Tiger Beetles (Coleoptera: Cicindelidae): Indicator Taxon for Biodiversity and Conservation Studies. Conservation Biology 6 (3): 376391. DOI:10.1046/j.1523-1739.1992.060303 76.x

Perera, N. P. (1975). A Physiognomic Vegetation Map of Sri Lanka (Ceylon). Journal of Biogeography 2 (3): 185-203.

Pethiyagoda, R. (2012). Biodiversity conservation in Sri Lanka's novel ecosystems. Ceylon Journal of Science, 41 (1): 1 - 10. DOI: http://dx.doi.org/10.4038/cjsbs.v41i1. 4532

Prendergast, J. R., Quinn, R. M., Lawton, J. H., Eversham, B. C. and Gibbons, D. W. (1993). Rare species, the coincidence of diversity hotspots and conservation strategies. Nature 365: $335-337$.

Ranasinghe, P. N., Dissanayake, C. B., Samarasinghe, D. V. N. and Galapatti, R. (2006). The relationship between soil geochemistry and dieback of montane forests in Sri Lanka: a case study. Journal of Environmental Geology 51 (6): 1077-1088.

Ranawana, K. B., Anoma Perera, Mahinda Ranasinhe and Omend de Silva. (2004). Assessment of potential interventions in the Knuckles range of forests, based on participatory approaches, IUCN, Colombo, Sri Lanka.

Rathnayaka, H. D. (1994). A plant ecological study of upper Montane rain forests of the Knuckles, Sri Lanka. M. Phil. Thesis, Department of Botany, Faculty of Science, University of Peradeniya, Sri Lanka. 
Rathnayake, R. M. W. R. and Jayasekara, L. R. (1998). Threatened endemic vegetation in the upper montane rain forest in Hakgala Strict Nature Reserve. The Sri Lankan Forester 23 (1 and 2): 17-21.

Redding, D. W. and Mooers, A. Ø. (2006). Incorporating evolutionary measures into conservation prioritization. Conservation Biology 20 (6): 1670 - 1678.

Sarmiento, F. O. (1995). Human impacts on the cloud forests of Upper Guayllabamba river basin, Ecuador, and suggested management responses. Ecological Studies 110: 284-295.

Scott, M. J., Davis, F., Csuti, B., Noss, R., Butterfield, B., Groves, C., Anderson, H., Caicco, S., D'Erchia, F., Edwards, T. C., Ulliman, J. and Wright, R. G. (1993) Gap analysis: a geographic approach to protection of biological diversity. Wildlife Monograph 123: 1-41.

Singh, A. and Samant, S. S. (2010). Conservation prioritization of habitats and forest communities in the Lahaul valley of proposed cold desert biosphere reserve, north western Himalaya, India. Applied Ecology and Environmental research 8 (2): 101-117

Soulé, M. (Ed.) (1986). Conservation Biology; the science of scarcity and diversity. Sinauer Associates, Sunderland, Massachusetts.

Still, C. J., Foster, P. N. and Schneider, S. H. (1999). Simulating the effects of climate change on tropical montane cloud forests Nature 398: 608-610

Symington, C. F. (1943). Forester's manual of dipterocarps. Malayan Forest Records 16:141.

The National Red List of Flora and Fauna of Sri Lanka (2012). The National Red List 2012 of Sri Lanka: Conservation status of the Fauna and Flora. BDS Secretariat of the Ministry of Environment and the Department of National Botanic Gardens, Colombo and Peradeniya, Sri Lanka.

Trigas, P., Panitsa, M. and Tsiftsis, S. (2013). Elevational Gradient of Vascular Plant Species Richness and Endemism in Crete The Effect of Post-Isolation Mountain Uplift on a Continental Island System. PLoS ONE 8
(3): e59425. doi:10.1371/journal.pone.0059 425

Trimen, H. (1885). Remarks on the composition, geographical affinities and origin of the Ceylon flora. Journal of Royal Asiatic Society 9 (2): 139-159.

Usher, M. B. (Ed.). (1986). Wildlife conservation evaluation. Chapman and Hall, London.

Vincent, F. D. A. (1883). The forests of Ceylon. Tropical Agriculturist 2(1-2), 280-281.

Werner, W. L. (1982). The upper montane rain forest of Sri Lanka. The Sri Lanka Forester, 15 (3 and 4): 119-129.

White, F. (1983). The Vegetation Africa. UNESCO, Paris.

Whitmore, T. C. (1975). Tropical Rain Forests of the Far East. Oxford University Press, London.

Wijesundara, D. S. A. (1991). Phytosociology of a montane forest in Sri Lanka, M.Phil. Thesis, Faculty of Science, University of Peradeniya, Sri Lanka.

Wijesundra, D. S. A. (2012). Present Status of Montane Forests in Sri Lanka. The National Red List 2012 of Sri Lanka: Conservation status of the Fauna and Flora. BDS Secretariat of the Ministry of Environment and the Department of National Botanic Gardens, Colombo and Peradeniya, Sri Lanka.

Wijesundra, D. S. A., Kathriarachchi, H.S., Ranasinghe, S. W. and Hapuarachchi, G. (2012). Analysis of Seed Plants of Sri Lanka. The National Red List 2012 of Sri Lanka: Conservation status of the Fauna and Flora. BDS Secretariat of the Ministry of Environment and the Department of National Botanic Gardens, Colombo and Peradeniya, Sri Lanka.

Young, K. R. and León, B. (1995). Distribution and Conservation of Peru's Montane Forests: Interactions between the Biota and Human Society. In: Tropical Montane Cloud Forests, Ecological Studies Volume 110, pp 363-376. Lawrence S. Hamilton, James O. Juvik and F. N. Scatena (Editors) SpringerVerlag, New York. 
Appendix 1. Plant families and species in TMCFs at Dothalugala MAB Reserve and their conservation status. (T-Tree; S-Shrub; C-Climber; E-endemic; N-national threat status and G-global threat status, CRCritically endangered; EN-Endangered; VU-Vulnerable and NT-Near Threatened).

\begin{tabular}{|c|c|c|c|c|}
\hline Scientific Name & $\begin{array}{l}\text { Life } \\
\text { form }\end{array}$ & $\mathrm{E}$ & $\mathrm{N}$ & $\mathrm{G}$ \\
\hline \multicolumn{5}{|l|}{ ANACARDIACEAE } \\
\hline Nothopegia beddomei Gamble & $\mathrm{T}$ & -- & -- & -- \\
\hline Semecarpus nigro-viridis Thw. & $\mathrm{T}$ & $\mathrm{E}$ & -- & VU \\
\hline \multicolumn{5}{|l|}{ ANNONACEAE } \\
\hline Mitrephora heyneana (Hook.f. \& Thoms.) Thw. & $\mathrm{T}$ & -- & NT & -- \\
\hline \multicolumn{5}{|l|}{ APOCYNACEAE } \\
\hline Gymnema pergularioides (Thw.) Hook.f. & $\mathrm{C}$ & $\mathrm{E}$ & VU & -- \\
\hline Rauvolfia densiflora (Wall.) Benth.ex Hook.f. & S & -- & & \\
\hline Tylophora pauciflora Wight \& Arn.ex Wight & S & -- & $\mathrm{EN}$ & -- \\
\hline \multicolumn{5}{|l|}{ AQUIFOLIACEAE } \\
\hline Ilex denticulata Wall. & $\mathrm{T}$ & -- & $\mathrm{EN}$ & -- \\
\hline Ilex walkeri Wight \& Gardner ex Thw. & $\mathrm{S}$ & -- & -- & -- \\
\hline \multicolumn{5}{|l|}{ ARACEAE } \\
\hline Pothos remotiflorus Hook. & $\mathrm{C}$ & $\mathrm{E}$ & VU & -- \\
\hline \multicolumn{5}{|l|}{ ARALIACEAE } \\
\hline Schefflera exaltata (Thw.) Frodin & $\mathrm{T}$ & $\mathrm{E}$ & $\mathrm{EN}$ & -- \\
\hline \multicolumn{5}{|l|}{ ASPARAGACEAE } \\
\hline Asparagus falcatus L. & $\mathrm{C}$ & -- & -- & -- \\
\hline \multicolumn{5}{|l|}{ ASTERACEAE } \\
\hline $\begin{array}{l}\text { Senecio corymbosus Wall. ex DC. var. walkeri (Arn.) } \\
\text { Grierson }\end{array}$ & \multicolumn{3}{|c|}{ Grierson } & -- \\
\hline Vernonia gardneri Thw. & S & $\mathrm{E}$ & VU & -- \\
\hline Vernonia wightiana Arn. & $\mathrm{S}$ & $\mathrm{E}$ & VU & -- \\
\hline Vernonia zeylanica (L.) Less & $\mathrm{S}$ & $\mathrm{E}$ & -- & -- \\
\hline \multicolumn{5}{|l|}{ BUXACEAE } \\
\hline Sarcococca zeylanica Baill. & $\mathrm{S}$ & $\mathrm{E}$ & VU & -- \\
\hline \multicolumn{5}{|l|}{ CALOPHYLLACEAE } \\
\hline Calophyllum trapezifolium Thw. & $\mathrm{T}$ & $\mathrm{E}$ & VU & -- \\
\hline \multicolumn{5}{|l|}{ CANNABACEAE } \\
\hline Celtis timorensis Span. & $\mathrm{T}$ & -- & -- & -- \\
\hline \multicolumn{5}{|l|}{ CELASTRACEAE } \\
\hline Cassine congylos Kosterm. & $\mathrm{T}$ & $\mathrm{E}$ & VU & -- \\
\hline Euonymus walkeri Wight & S & $\mathrm{E}$ & -- & VU \\
\hline Microtropis wallichiana Wight ex Thw. & $\mathrm{T}$ & -- & & \\
\hline Salacia reticulata Wight & $\mathrm{C}$ & -- & $\mathrm{EN}$ & -- \\
\hline \multicolumn{5}{|l|}{ CENTROPLACACEAE } \\
\hline \multicolumn{5}{|l|}{ CLUSIACEAE } \\
\hline Garcinia echinocarpa Thw. & $\mathrm{T}$ & -- & VU & -- \\
\hline \multicolumn{5}{|l|}{ CONVOLVULACEAE } \\
\hline Argyreia hirsuta Arn. & $\mathrm{C}$ & -- & -- & -- \\
\hline \multicolumn{5}{|l|}{ DIOSCOREACEAE } \\
\hline Dioscorea trimenii Prain \& Burkill & $\mathrm{C}$ & $\mathrm{E}$ & $\mathrm{EN}$ & -- \\
\hline \multicolumn{5}{|l|}{ DIPTEROCARPACEAE } \\
\hline Stemonoporus affinis Thw. & $\mathrm{T}$ & $\mathrm{E}$ & $\mathrm{CR}$ & CR \\
\hline \multicolumn{5}{|l|}{ ELAEAGNACEAE } \\
\hline Elaegnus latifolia $\mathrm{L}$. & $\mathrm{S}$ & -- & -- & -- \\
\hline \multicolumn{5}{|l|}{ ELAEOCARPACEAE } \\
\hline Elaeocarpus glandulifer (Hook.) Masters & $\mathrm{T}$ & $\mathrm{E}$ & VU & VU \\
\hline Elaeocarpus hedyosmus Zmarzty & $\mathrm{S}$ & $\mathrm{E}$ & $\mathrm{EN}$ & -- \\
\hline
\end{tabular}




\begin{tabular}{|c|c|c|c|c|}
\hline Scientific Name & $\begin{array}{l}\text { Life } \\
\text { form }\end{array}$ & $\mathrm{E}$ & $\mathrm{N}$ & $\bar{G}$ \\
\hline \multicolumn{5}{|l|}{ ERYTHROXYLACEAE } \\
\hline Erythroxylum monogynum Roxb. & $\mathrm{S}$ & -- & NT & -- \\
\hline \multicolumn{5}{|l|}{ EUPHORBIACEAE } \\
\hline Agrostistachys coriacea Alston & $\mathrm{S}$ & $\mathrm{E}$ & -- & VU \\
\hline Croton laccifer $\mathrm{L}$. & $\mathrm{S}$ & -- & -- & -- \\
\hline Fahrenheitia minor (Thw.) Airy Shaw & $\mathrm{S}$ & -- & -- & -- \\
\hline Fahrenheitia zeylanica (Thwaites)Airy Shaw & $\mathrm{S}$ & -- & -- & -- \\
\hline Macaranga peltata (Roxb.) Muell.Arg. & $\mathrm{T}$ & -- & -- & -- \\
\hline Mallotus fuscescens (Thw.) Muell.Arg. & $\mathrm{T}$ & $\mathrm{E}$ & -- & -- \\
\hline Mallotus philippensis (Lam.) Muell.Arg. & $\mathrm{T}$ & -- & -- & -- \\
\hline Trigonostemon nemoralis Thw. & $\mathrm{S}$ & -- & VU & -- \\
\hline \multicolumn{5}{|l|}{ FABACEAE } \\
\hline Dalbergia pseudo-sissoo Miq. & $\mathrm{C}$ & -- & -- & -- \\
\hline \multicolumn{5}{|l|}{ 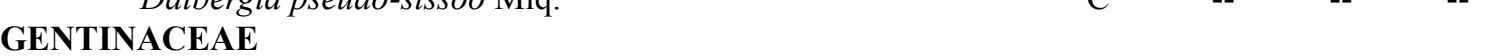 } \\
\hline Fagraea ceilanica Thunb. & $\mathrm{T}$ & -- & NT & -- \\
\hline \multicolumn{5}{|l|}{ ICACINACEAE } \\
\hline Apodytes dimidiata E. Meyer ex Arn. & $\mathrm{T}$ & -- & VU & -- \\
\hline Nothapodytes nimmoniana (Graham) Mabb. & $\mathrm{T}$ & -- & NT & -- \\
\hline \multicolumn{5}{|l|}{ LAMIACEAE } \\
\hline Callicarpa tomentosa (L.) Murr & $\mathrm{S}$ & -- & -- & -- \\
\hline \multicolumn{5}{|l|}{ LAURACEAE } \\
\hline Actinodaphne ambigua (Meissner) Hook.f. & $\mathrm{T}$ & $\mathrm{E}$ & -- & -- \\
\hline Actinodaphne elegans Thw. & $\mathrm{T}$ & $\mathrm{E}$ & -- & -- \\
\hline Actinodaphne moonii Thw. & $\mathrm{T}$ & $\mathrm{E}$ & VU & -- \\
\hline Actinodaphne stenophylla Thw. & $\mathrm{T}$ & $\mathrm{E}$ & VU & -- \\
\hline Cinnamomum litseaefolium Thw. & $\mathrm{T}$ & $\mathrm{E}$ & EN & -- \\
\hline Cinnamomum ovalifolium Wight & $\mathrm{T}$ & $\mathrm{E}$ & VU & -- \\
\hline Cryptocarya wightiana Thw. & $\mathrm{T}$ & -- & NT & VU \\
\hline Litsea gardneri (Thw.) Meissner & $\mathrm{T}$ & $\mathrm{E}$ & VU & VU \\
\hline Litsea glaberrima (Thw.) Trimen & $\mathrm{T}$ & E & NT & EN \\
\hline Litsea glutinosa (Lour.) C.B.Robinson & $\mathrm{T}$ & -- & -- & -- \\
\hline Litsea walkeri (Meissner) Trimen & $\mathrm{T}$ & $\mathrm{E}$ & VU & -- \\
\hline Neolitsea fuscata (Thw.) Alston & $\mathrm{T}$ & $\mathrm{E}$ & VU & -- \\
\hline Persea macrantha (Nees) Kosterm. & $\mathrm{T}$ & -- & VU & -- \\
\hline \multicolumn{5}{|l|}{ LOGANIACEAE } \\
\hline Strychnos benthamii C.B.Clarke & $\mathrm{S}$ & E & NT & -- \\
\hline \multicolumn{5}{|l|}{ MELASTOMATACEAE } \\
\hline Kendrickia walkeri (Wight ex Gardner) Triana & $\mathrm{C}$ & -- & VU & -- \\
\hline Lijndena gardneri (Thw.) Bremer & $\mathrm{S}$ & $\mathrm{E}$ & VU & -- \\
\hline Memecylon cuneatum Thw. & $\mathrm{T}$ & $\mathrm{E}$ & EN & -- \\
\hline Memecylon fuscescens Thw. & $\mathrm{S}$ & $\mathrm{E}$ & EN & -- \\
\hline Memecylon sessile Benth. & $\mathrm{S}$ & -- & $\mathrm{CR}$ & -- \\
\hline Osbeckia lanata Alston. & $\mathrm{S}$ & E & EN & -- \\
\hline \multicolumn{5}{|l|}{ MELIACEAE } \\
\hline Aglaia apiocarpa (Thw.) Hiern. & $\mathrm{T}$ & -- & -- & VU \\
\hline Aglaia elaeagnoidea (A.Juss.) Benth. & $\mathrm{T}$ & -- & -- & -- \\
\hline \multicolumn{5}{|l|}{ MENISPERMACEAE } \\
\hline Cyclea peltata (Burm.f.) Hook.f. \& Thoms. & $\mathrm{C}$ & -- & -- & -- \\
\hline Stephania japonica (Thunb.) Miers & $\mathrm{C}$ & -- & VU & -- \\
\hline \multicolumn{5}{|l|}{ MONIMIACEAE } \\
\hline \multirow{2}{*}{\multicolumn{5}{|c|}{ MORACEAE }} \\
\hline & & & & \\
\hline Ficus diversiformis Miq. & $\mathrm{S}$ & E & -- & -- \\
\hline Ficus hispida L.f. & $\mathrm{T}$ & -- & -- & -- \\
\hline Ficus nervosa Heyne ex Roth & $\mathrm{T}$ & -- & -- & -- \\
\hline
\end{tabular}




\begin{tabular}{|c|c|c|c|c|}
\hline Scientific Name & $\begin{array}{l}\text { Life } \\
\text { form }\end{array}$ & E & $\mathrm{N}$ & G \\
\hline \multicolumn{5}{|l|}{ MYRISTICACEAE } \\
\hline Myristica ceylanica A. DC. & $\mathrm{T}$ & -- & VU & VU \\
\hline Myristica dactyloides Gaertn. & $\mathrm{T}$ & -- & -- & -- \\
\hline \multicolumn{5}{|l|}{ MYRTACEAE } \\
\hline Eugenia cotinifolia Jacq. & $\mathrm{S}$ & -- & -- & -- \\
\hline Eugenia mabaeoides Wight & $\mathrm{T}$ & E & -- & -- \\
\hline Eugenia thwaitessii Duthie & $\mathrm{T}$ & -- & -- & -- \\
\hline Syzygium assimile Thw. & $\mathrm{T}$ & $\mathrm{E}$ & -- & -- \\
\hline Syzygium caryophyllatum (L.) Alston & $\mathrm{T}$ & -- & -- & EN \\
\hline Syzygium fergusoni Gamble & $\mathrm{T}$ & E & VU & EN \\
\hline Syzygium makul gaertn. & $\mathrm{T}$ & -- & -- & -- \\
\hline Syzygium micranthum Thw. & $\mathrm{T}$ & $\mathrm{E}$ & -- & -- \\
\hline Syzygium revolutum Walp. & $\mathrm{T}$ & E & -- & -- \\
\hline Syzygium spathulatum Thw. & $\mathrm{T}$ & E & -- & -- \\
\hline \multicolumn{5}{|l|}{ OLEACEAE } \\
\hline Chionanthus albidiflora Thw. & $\mathrm{T}$ & E & VU & -- \\
\hline Chionanthus zeylanica L. & $\mathrm{T}$ & -- & -- & -- \\
\hline Jasminum flexile Vahl & $\mathrm{C}$ & -- & -- & -- \\
\hline Olea polygama Wight & $\mathrm{T}$ & -- & -- & -- \\
\hline \multicolumn{5}{|l|}{ PANDANACEAE } \\
\hline Freycinetia pycnophylla Solms & $\mathrm{C}$ & E & VU & -- \\
\hline \multicolumn{5}{|l|}{ PENTAPHYLACEAE } \\
\hline Eurya ceylanica Wight & $\mathrm{T}$ & E & VU & -- \\
\hline Ternstroemia gymnanthera (Wight \& Arn.) Beddome & $\mathrm{T}$ & -- & EN & -- \\
\hline \multicolumn{5}{|l|}{ PHYLLANTHACEAE } \\
\hline Actephila excelsa (Dalz.) Muell.Arg. & $\mathrm{T}$ & -- & -- & -- \\
\hline Antidesma pyrifolium Muell. Arg. & $\mathrm{T}$ & E & -- & VU \\
\hline Aporusa fusiformis Thw. & $\mathrm{T}$ & -- & VU & -- \\
\hline Breynia vitis-idaea (Burm.f.) C.E.C.Fischer & $\mathrm{S}$ & E & -- & -- \\
\hline Glochidion pachycarpum Alston & $\mathrm{T}$ & E & -- & -- \\
\hline Glochidion stellatum (Retz.) Beddome & $\mathrm{T}$ & $\mathrm{E}$ & -- & -- \\
\hline Phyllanthus cinereus Muell. Arg. & $\mathrm{S}$ & $\mathrm{E}$ & VU & -- \\
\hline \multicolumn{5}{|l|}{ PIPERACEAE } \\
\hline Piper sylvestre Lam. & $\mathrm{C}$ & -- & -- & -- \\
\hline Piper zeylanicum Miq. & $\mathrm{C}$ & E & -- & -- \\
\hline \multicolumn{5}{|l|}{ PITTOSPORACEAE } \\
\hline Pittosporum tetraspermum Wight \& Arn. & $\mathrm{T}$ & -- & VU & -- \\
\hline \multicolumn{5}{|l|}{ POACEAEA } \\
\hline Arundinaria debilis Thw. & $\mathrm{S}$ & $\mathrm{E}$ & EN & -- \\
\hline Davidsea attenuata (Thw.) Soderstrom \& Ellis & $\mathrm{S}$ & $\mathrm{E}$ & VU & -- \\
\hline \multicolumn{5}{|l|}{ PRIMULACEAE } \\
\hline Ardisia gardneri Clarke & $\mathrm{S}$ & $\mathrm{E}$ & -- & -- \\
\hline Maesa indica (Roxb.) A.DC. & $\mathrm{S}$ & -- & -- & -- \\
\hline Myrsine robusta (Mez) Wadhaw & $\mathrm{T}$ & $\mathrm{E}$ & -- & -- \\
\hline \multicolumn{5}{|l|}{ ROSACEAE } \\
\hline Rubus gardnerianus Kuntz & $\mathrm{C}$ & -- & NT & -- \\
\hline Rubus indicus Thunb. & $\mathrm{C}$ & -- & -- & -- \\
\hline \multicolumn{5}{|l|}{ RUBIACEAE } \\
\hline Canthium coromandelicum (Burm.f.) Alston & $\mathrm{S}$ & -- & -- & -- \\
\hline Gaertnera walkeri (Arn.) Blume & $\mathrm{S}$ & $\mathrm{E}$ & NT & VU \\
\hline Hedyotis flavescens Thw. & $\mathrm{S}$ & E & NT & -- \\
\hline Hedyotis fumata Alston & $\mathrm{S}$ & $\mathrm{E}$ & VU & -- \\
\hline Hedyotis lessertiana Arn. & $\mathrm{S}$ & -- & -- & -- \\
\hline
\end{tabular}




\begin{tabular}{|c|c|c|c|c|c|}
\hline Family & Scientific Name & $\begin{array}{l}\text { Life } \\
\text { form }\end{array}$ & $\mathrm{E}$ & $\mathrm{N}$ & G \\
\hline \multicolumn{6}{|c|}{ RUBIACEAE (contd.) } \\
\hline & Hedyotis trimenii Deb \& Dutta & $\mathrm{S}$ & E & -- & -- \\
\hline & Ixora jucanda Thw. & $\mathrm{T}$ & E & -- & -- \\
\hline & Lasianthus foetulentus Ridsd. & $\mathrm{S}$ & $\mathrm{E}$ & VU & -- \\
\hline & Lasianthus strigosus Wight & $\mathrm{S}$ & E & -- & -- \\
\hline & Morinda umbellata $\mathrm{L}$. & $\mathrm{C}$ & -- & -- & -- \\
\hline & Psychotria gardneri (Thw.) Hook.f. & $\mathrm{S}$ & E & NT & -- \\
\hline & Psychotria nigra (Gaertn.) Alston & $\mathrm{S}$ & -- & -- & -- \\
\hline & Psychotria sordida Thw. & $\mathrm{S}$ & $\mathrm{E}$ & VU & -- \\
\hline & Psydrax dicoccos Gaertn. & $\mathrm{T}$ & -- & -- & -- \\
\hline & Saprosma foetens (Wight) Schumann & $\mathrm{S}$ & E & -- & -- \\
\hline & Urophyllum ceylanicum (Wight) Thw. & $\mathrm{S}$ & E & -- & -- \\
\hline \multicolumn{6}{|c|}{ RUTACEAE } \\
\hline & Acronychia pedunculata (L.) Miq. & $\mathrm{T}$ & -- & -- & -- \\
\hline & Melicope lunu-ankenda (Gaertn.) T. Hartley & $\mathrm{T}$ & -- & -- & -- \\
\hline & Toddalia asiatica (L.) Lam. & $\mathrm{C}$ & -- & -- & -- \\
\hline \multicolumn{6}{|c|}{ SALICACEAE } \\
\hline & Casearia thwaitesii Briq. & $\mathrm{T}$ & -- & VU & -- \\
\hline & Casearia zeylanica (Gaertn.) Thw. & $\mathrm{T}$ & -- & -- & -- \\
\hline & Flacourtia indica (Burm.f.)Merr. & $\mathrm{T}$ & -- & -- & -- \\
\hline & Flacourtia inermis Roxb. & & & & \\
\hline & Scolopia crassipes Clos & $\mathrm{T}$ & E & -- & -- \\
\hline \multicolumn{6}{|c|}{ SAPINDACEAE } \\
\hline & Allophylus zeylanicus $\mathrm{L}$. & $\mathrm{T}$ & E & -- & -- \\
\hline \multicolumn{6}{|c|}{ SAPOTACEAE } \\
\hline & Isonandra zeylanica Jeuken & $\mathrm{S}$ & $\mathrm{E}$ & VU & -- \\
\hline & Palaquium rubiginosum (Thw.)Engl. & $\mathrm{T}$ & $\mathrm{E}$ & VU & VU \\
\hline \multicolumn{6}{|c|}{ SMILACACEAE } \\
\hline & Smilax aspera $\mathrm{L}$. & $\mathrm{C}$ & -- & VU & -- \\
\hline & Smilax zeylanica $\mathrm{L}$. & $\mathrm{C}$ & -- & -- & -- \\
\hline \multicolumn{6}{|c|}{ STAPHYLEACEAE } \\
\hline & Gomphandra coriacea Wight & $\mathrm{T}$ & -- & VU & -- \\
\hline \multicolumn{6}{|c|}{ STEMONURACEAE } \\
\hline & Turpinia malabarica Gamble & $\mathrm{T}$ & -- & -- & -- \\
\hline \multicolumn{6}{|c|}{ SYMPLOCACEAE } \\
\hline & Symplocos cochinchinensis (Lour.) S.Moore & $\mathrm{T}$ & -- & & \\
\hline & Symplocos cordifolia Thw. & $\mathrm{T}$ & $\mathrm{E}$ & EN & VU \\
\hline & Symplocos elegans Thw. & $\mathrm{T}$ & E & VU & -- \\
\hline \multicolumn{6}{|c|}{ THEACEAE } \\
\hline & Gordonia ceylanica Wight & $\mathrm{T}$ & E & EN & -- \\
\hline \multicolumn{6}{|c|}{ VITACEAE } \\
\hline & Cayratia pedata (Lam.) Juss.ex Gagnep. & $\mathrm{C}$ & -- & -- & -- \\
\hline & Cissus gardneri Thw. & $\mathrm{C}$ & E & -- & -- \\
\hline & Cissus trilobata Lam. & $\mathrm{C}$ & -- & -- & -- \\
\hline & Tetrastigma nilagiricum (Miq.) Shetty & $\mathrm{C}$ & -- & -- & -- \\
\hline \multicolumn{6}{|c|}{ ZINGIBERACEAE } \\
\hline & Zingiber cylindricum Thw. & $\mathrm{H}$ & E & VU & -- \\
\hline
\end{tabular}

